\title{
KEAP1 Gene Mutation
}

National Cancer Institute

\section{Source}

National Cancer Institute. KEAP1 Gene Mutation. NCI Thesaurus. Code C129685.

A change in the nucleotide sequence of the KEAP1 gene. 